\title{
Explaining the labour performance of immigrant women in Spain: the interplay between family, migration and legal trajectories
}

\author{
Amparo González-Ferrer ${ }^{* \dagger}$
}

\begin{abstract}
The labour performance of migrants has been largely assumed to vary with individuals' reasons to migrate. Accordingly, migrants who migrate to join their relatives at destination are commonly expected to be negatively selected in terms of their labour characteristics. However, family and economic reasons for migration are not mutually exclusive but often complementary, especially among women. In addition, there exists a large variation in the post-migration employment rates of the so-called 'family migrants'. In this article, I argue that the temporal sequence of migration and key family life-cycle events may help us in explaining the post-migration employment patterns of migrants, especially that of females. To test this hypothesis I first construct a comprehensive typology that classifies all immigrants according to the timing of marriage and migration for each spouse, and their immigrant or native origin. Next, I examine the explanatory power of this typology by estimating the employment probability of of migrants in multivariate logit regressions that include the resulting types of 'family migrants' as independent. Our results confirm the theoretical and empirical utility of studying marriage and migration jointly in order to explain differences in the labour performance of immigrant women. Moreover, our main conclusions concerning cross-types differences in female labour behaviour remain valid ever after controlling for current legal status and legal status at entry, and running separate analyses for the main origin groups in Spain.
\end{abstract}

\footnotetext{
* I am grateful to all the attendants to the Conference 'Immigrants' economic incorporation, spatial segregation and anti-immigrant sentiments' held at the Juan March Institute in October 2009 for helpful suggestions to a previous version of this chapter. All mistakes are mine.

${ }^{\dagger}$ Institute of Economy, Geography and Demography. Spanish Research Council. Albasanz, 26-28, Madrid 28037. amparo.gonzalez@cchs.csic.es
} 


\section{Introduction}

Contemporary societies are becoming multi-ethnic at a very fast pace as a result of the recent growth in international migration trends. This introduces new sources of socioeconomic heterogeneity in receiving societies related to the distinctiveness of immigrant households. Generally speaking immigrants fare comparatively poorly on many economic indicators such as relative incomes, poverty, employment, etc., which feed the public concerns about the potential social exclusion of immigrant families and the ethnification of inequality in receiving countries. Low employment rates of immigrant women constitute a major concern in this regard, given the crucial role of female incomes in avoiding household poverty, especially in contexts where two-earner households are becoming the norm. However, our understanding of the main determinants of the labour performance of immigrant women remains quite limited, and often dominated by stereotypical views that equate female migration with economically inactive family dependants.

In this article, I challenge this view using empirical evidence from recent international migration to Spain. First, I illustrate the existence of great heterogeneity in both reasons to migrate and employment trajectories among immigrant women. Secondly, I try to account for such heterogeneity analyzing migration and family trajectories jointly. The rest of the article is organized as follows. In Section 2 I review previous research dealing with the main issues of interest for this article, and describe the characteristics of recent international migration to Spain and the main features of the Spanish visa and residence system in Section 3. Next, in Section 4, I formulate the main hypotheses to be tested, and present the data in Section 5. Finally, I estimate and discuss the results in Section 6 and conclude in Section 7.

\section{Previous research about family-linked migration and economic integration outcomes}

Much of the empirical research concerned with the impact of family migration on the labour performance of women has focused on internal rather than international migration., According to the family migration model inspired in the human capital theory (Sandell 1977, Taylor 1978), women are expected to experience smaller returns 
to migration than their husbands due to their usually discontinuous attachment to the labour force, and also to suffer from higher unemployment and lower participation rates immediately after migration because of "the higher value that the family attaches to her market time in order to set up the new household at destination" (Sandell, 1977: 407).

Most empirical research has supported, up to date, this disruption hypothesis as regarding the effects of family internal migration on the labour market performance of wives. In contrast, the employment-related consequences of migration for women have been far less explored in the context of international migration ${ }^{1}$. Yet, this has not prevented from a generalized and stereotypical view of international immigrant women as 'tied-movers' who will not work at destination in most of the specialized literature ${ }^{2}$. The assumption that women's migration is linked to family rather than economic motives, the inherent difficulties in studying female labour behaviour (career interruptions, family-life cycle factors, occupational sex-segregation, etc.) and the lack of adequate datasets help explaining the little evidence available in this area.

However, there exist some studies that actually support a negative view of family migrants as having harmful effects on the host economy. In the US, class of admission remains a significant correlate of immigrant labour performance, in terms of occupational attainment and earnings. Even after controlling for observable human capital characteristics and region of origin, employment-preference immigrants are able to keep higher prestige scores than both refugees and family-based immigrants (Akresh 2006), despite of the substantial occupational upgrading experienced by the latter that could serve to erase cross-group differences after 12 to 18 years in the country (Jasso and Rosenweizg 1997; Duleep and Regets 1996). In Europe, Constant and Zimmermann (2006) have also concluded that there are long-lasting effects of the category of admission on the employment choices and earnings potential of immigrants in Germany, especially for immigrants admitted on the basis of asylum but also for those entering for family reunification. If family migrants work little and earn less than economic migrants, an increase in family reunification flows is expected to increase the

\footnotetext{
${ }^{1}$ The 'Family Investment Hypothesis' (Long 1980) constitutes one of the few exceptions in this regard, but its reasoning only applies to women who migrated at the same time or immediately after their husbands (see AUTHOR A 2006a).

2 Tied-movers in family migration decisions are those who participate in moves that result in a loss for themselves but their loss is exceeded by the family gain..
} 
number of non-working people in immigrant households and, thus, the economic dependency ratio among the immigrant population

This evidence has contributed to reinforce the image of family migration as contrary to economic migration and of a type that is potentially harmful for the host economy. However, at least three major limitations may seriously challenge the conclusions of these studies. First of all, they all measure the impact of the admission category on the labour market performance of immigrants; thus, their results are hardly surprising since they probably reflect the common barriers that immigration policies generally impose on migrants admitted on non-employment grounds, rather than unobserved characteristics of family immigrants that correlate with their labour performance. In addition, immigrants admitted on the basis of their family ties with other residents do not exhaust family-linked migration but just the narrowest legal version of it. Much irregular migration is often made of family migrants (see Massey 2003, Cornelius et al. 2008 for the US, and AUTHOR A 2008, 2010 for Spain). Accordingly, a comprehensive assessment of the labour performance of family migrants and, more generally, of the links between family reasons to migrate and migrants' economic performance at destination should include also them.

Secondly, none of these studies included information on current legal status jointly with the category of admission, and undocumented migrants were systematically excluded from the analyses, which may lead to radically misleading conclusions about the efficacy of immigration policy in their role of selecting migrants, and about the actual trends and determinants of immigrants' economic incorporation in their host societies (Massey and Bartley 2006: 472).

Thirdly, and more important, these studies have largely restricted to men's experiences, while it is well-known that women largely outnumber men in family-related migration categories. In fact, many studies have proved that migration decisions are gendered (Zlotnik 1995a, 1995b, Massey et al. 1987, Stier and Tienda 1992, Kanaiaupuni 1995, Donato and Kanaiaupuni 2000, Parrado 2004); moreover, some studies provide premilinary evidence that gender differences go beyond the migration decision and also emerge in the post-migration labour behaviour patterns of men and women. For instance, having a native partner (Baker and Benjamin 1997, Meng and Gregory 2005) 
or being single at the time of arrival (Duleep and Regets 1993, Cerruti and Massey 2001) are found to increase the employment chances (and/or wages) of immigrant women, but these same factors are not equally relevant to explain the labour performance of immigrant men. Moreover, some authors have also found significant differences between different types of female family migrants, like reunified wives -for whom marriage pre-existed the migration of both spouses-, and imported wives -who had not yet married/met their husband at the time he migrated- with regard to their educational levels and investments in education, their household living arrangements and also their labour performance at destination (Nielsen et al. 2007, AUTHOR A 2006b).

However, we still lack a comprehensive analysis of the joint effect of marriage, marital status at migration and relative timing of migration within the couple, and their potential effect on migrants' post-migration behaviour (see Hondegnau-Sotelo 1994 and AUTHOR A 2006a for exceptions). Even more, we know very little about how immigration regulations and labour market policies interact with these family life-cycle events in shaping the labour behaviour of immigrants, which seems particularly crucial in contexts like the Spanish one, where some flows are highly feminized, a strong demand for cheap labour in women's occupations exists, and immigration policies have not effectively discouraged undocumented residence and activity in the black economy.

\section{International migration to Spain and its regulation}

Spanish immigration experience has called the attention of many scholars and policymakers because of its sharp increase in a very short time; but also because of the large amount of undocumented immigrants who have periodically been regularised. The difference between the number of foreigners in the Municipal Population Register (which does not require to demonstrate legal status) and the number of valid residence permits in the same year, some authors estimated that the percentage of foreigners living in Spain without the proper residence permit could represent up to the 70 percent of the total foreign population in 2002, 40 percent in 2005 and 24 percent in 2007 (AUTHOR B and AUTHOR A 2007). 
The reasons for this situation, in which irregularity has become a structural feature of the Spanish immigration system, are mainly two: the absence of efficient and reliable doors of legal-entry, on the one hand, and the soft enforcement of both external and internal controls ${ }^{3}$. Legal admissions based on employers' official recruitment of foreign workers have traditionally represented a ridiculous share of total annual entries ${ }^{4}$, and other legal channels to enter the country like family reunification or asylum were for a long time either completely closed or very costly to follow. Namely, the administrative procedure to sponsor the legal immigration of immediate family members has been messy and extremely time-consuming until very recently, despite of the relatively soft legal requirements imposed by Spain in comparison to other countries like Denmark or the Netherlands. Even if the application for family reunification is accepted in Spain, it will still take a long time until reunification materializes because the sponsored relatives need to obtain a visa in their country of origin, which is the most uncertain and complicated step of the entire process (see more in AUTHOR A 2010).

The lack of a reasonably timely family reunification option within the legal system has probably contributed to the breakdown of the Spanish immigration system, which was fragile to begin with (see Hatch 2006 for a similar argument in the US). As can be seen in Figure 1, the number of non-EU foreigners living in Spain increased from about 1 million in 2000 to 3.5 million in 2006. Most newcomers entered the country legally as tourists but became irregular immigrants when their visas expired and they overstayed (see the difference between the line with squares and the line with crosses). On the other hand, the number of residence permits granted for the purpose of family reunification over the entire period amounted only to 420,000. It can be easily argued then that statistics of permits granted for the purpose of family reunification clearly underestimate the actual size of family-linked migration to Spain, and that a sizable proportion of the migrants who joined their relatives in Spain did so with following the legal procedure for family reunification.

\footnotetext{
${ }^{3}$ Brochmann and Hammar (1999) utilised this terminology to distinguish measures of immigration control implemented at the border (external) and within the territory (internal).

${ }^{4}$ Approximately 3 percent of total entries (legal and irregular ones) during the period 2002-2007 (CeiMigra 2008: 7).
} 
Actually, foreign spouses who are willing to come to Spain have strong incentives to enter the country on tourist visas and overstay illegally, especially if they are interested in working in Spain. First of all, this route into Spain would allow them to join their spouses much sooner than the legal procedure of family reunification. Secondly, the labour status of spouses that overstay their tourist visas and that of legally reunified spouses is not very different upon arrival, since the latter cannot apply for a work permit until having resided in Spain for one year. Thirdly, and maybe the most important, the risks associated with an undocumented status in Spain have been substantially lower than in other EU countries. On the one hand, as we mentioned earlier, the enforcement of internal immigration controls has been traditionally soft in Spain, although undocumented foreigners are probably more fearful of expulsion now that they used to be three or five years ago ${ }^{5}$. In addition, the implementation of regularisation programs has been a common policy instrument during the last decade -since 2000 more than $1,300,000$ foreigners have obtained residence permits through this type of processwhich have definitely enhanced the incentives to overstay (De Bruycker 2000; AUTHOR B and AUTHOR A 2008; Baldwin-Edwards and Kraler 2009).

Given such a perverse set of incentives, it is not impossible to think that migrants who decided to utilise the slow and burdensome legal procedure for family reunification to come to Spain not only had a stronger aversion to break the law, but probably also a weaker preference for work. Moreover, the odds of becoming an irregular resident at some point in time have kept high due to both the precarious employment conditions of most migrants in Spain, and the link between employment and legal residency established in the Spanish foreigners' law. As result, entries and exits from the group of 'legal' residents have been common due to the short expiration period of most temporary residence permits granted during the multiple regularisation processes. For all these reasons, legal status at entry is expected to be negatively related with employment among immigrant women in Spain, once their current legal status is accounted for ${ }^{6}$.

\footnotetext{
${ }^{5}$ Expulsions effectively increased from approximately 1.3 percent of the estimated number of non-EU undocumented foreigners residing in Spain in 2003 to 2.5 in 2007. However, regardless of actual figures (which are quite low, in any case), the immigration and economic context has recently changed towards an increasing perception of undocumented status as a risky situation.

${ }^{6}$ As one anonymous reviewer noticed, this reasoning probably does not apply to high-skilled migrants.
} 


\section{Hypotheses}

Bearing in mind the reviewed findings in the previous literature and the particular characteristics of the Spanish immigration and labour market context, we can formulate the following hypotheses:

H1. Different types of family-linked migration are expected to be associated not only with systematic differences in (declared) reasons to migrate but also to systematic differences in post-migration labour performance, even after controlling for variation in reasons to migrate.

H1a. Namely, on the basis of previous findings and the varying degrees to which different sequences in the ordering of marriage and spouses' migration are expected to reveal either individual or household strategies, we expect the following ranking in the employment probability of female migrants (from most likely to least likely to be employed): single, single at migration but currently married (to an imported husband, to another immigrant, to a native), married at migration who preceded their husbands, married at migration who migrated jointly with their husbands, reunified wives and, finally, imported spouses ${ }^{7}$

H2. Increasing stability concerning legal status is expected to be associated with increasing employment probability of (female) migrants.

H3. However, we expect differences in employment across family-migration types to remain even after controlling for current legal status, given the extent of the informal economy in Spain, on the one hand, and the traditionally blurred frontier between regular and irregular status, which has affected all types of migrants.

H4. Finally, given the pervasive set of incentives created by the soft enforcement of norms against irregular migration, the existence of a strong demand for cheap labour in female occupations, the presence of a large informal economy and the slow and restrictive regime for family reunification of spouses, we expect 'followers' who utilized their family ties to be legally admitted to Spain to perform worse than those who just joined their relatives "de facto".

\footnotetext{
${ }^{7}$ Difference between reunified and imported spouses.....
} 


\section{Data and method}

The National Immigrants Survey (NIS) is a representative survey that collects information about the migration and settlement experience of nearly 15,500 foreignborn people, aged 16 or more and who lived in Spain in 2007, regardless of their legal status $^{8}$. Apart from its large sample size and representativeness, NIS has the advantage of including also a considerable amount of retrospective information on the interviewees and their closest relatives. By using this information it is possible a partial reconstruction of their migration, family, labour and legal trajectories that allow testing the hypotheses formulated in Section 4.

In the following section, I will examine the employment performance of immigrants in Spain by means of multivariate logistic regression, in which the dependent variable is 'being employed' (or not) at the time of the survey. I eliminated from the total sample individuals born in EU countries -because general immigration law do not apply to them; in addition, immigrants who arrived at age younger than 16 (the so-called 1.5 generation) were also excluded since they did not make their own migration decisions; finally, immigrants older than 55 at the time of the survey were also eliminated. The final sample size is 9,010 individuals, of which 4,122 are males and 4,888 females.

The multivariate analyses focus on the effects of the indicators for reasons to migrate, family-linked migration type, current legal status and legal status at entry, which are described in more detail in the following paragraphs. However, all the models included also the following controls: age at migration, years since migration, highest educational level attained, country of birth (Morocco, Romania, Ecuador, Colombia, Others), whether the immigrant had working experience before migrating to Spain or not, Spanish-language skills, whether the migrant had a work proposal before coming to Spain or not, and the number of children the migrant had at the time of the survey ${ }^{9}$. The discussion of the results restricts to immigrant women, but the results for men are also shown for the sake of comparison.

\footnotetext{
${ }^{8}$ Questionnaires were available in French, English, German, Romanian and Arab, apart from Spanish, which was the language mostly used during the interviews. .Complete documentation, including the different versions of the questionnaire, and microdata are freely available at http://www.ine.es/jaxi/menu.do?type=pcaxisandpath=\%2Ft $20 \% 2 \mathrm{Fp} 319$ andfile=inebaseandL=

${ }^{9}$ Available on request.
} 
In order to test the main hypotheses formulated above, I constructed a comprehensive typology that combines information on the nativity of the husband, the ordering of marriage and each spouse's migration to Spain (i.e. marriage before, after or at the same time at migration), and the sequence of both spouses' migration (i.e. who goes first or who follows whom). This typology has the enormous advantage of combining at once the three main factors the literature has paid attention to in order to explain the labour behaviour of immigrant women. Table 1 summarizes the resulting categories, their definition and the distribution of our sample according to them, by gender.

Insert Table 1 here

As can be seen, approximately 35 percent of women in our sample had not married yet at the time of the survey; 17 percent were not married at arrival but married someone during their stay in Spain: 7 percent married another immigrant in Spain, 8 percent married a native in Spain, and 2 percent married someone in their country of origin (potential importer and importer). On the other hand, approximately 34 percent of the female sample were already married at the time of their arrival to Spain: 13 percent came the same year as their husband, 5 percent came earlier (potential reunifier and reunifier), and 11 came after (of which, 3 percent by native husbands), and 5 percent were 'imported' by men of their same origin in Spain. It appears clear from the table that both 'reunified spouses' and 'imported spouses' are mostly a female phenomenon.

Apart from the described typology, we have also constructed three additional indicators aimed at measuring our main explanatory variables:

a) The individual's reasons to migrate. This variable has been constructed from the interviewees' answers to the question 'Why did you migrate to Spain?', which admitted multiple responses. Individuals are classified in four categories depending on whether they mentioned only economic reasons, only family-related reasons, a combination of both, or others. As can be seen in Table 2, economic reasons dominate among both men (58 percent) and also women (45 percent). Moreover, as we expected the proportion of women who mentioned both economic and family reasons as motives for their migration is larger than among men (12 versus 8 percent, respectively). Moreover, reunified wives -the traditional archetype of economically dependent family migrant- is 
the group for which the concurrence of economic and family reasons is most common (33 percent), followed by women who migrated jointly with their spouses (17 percent). In fact, only 47 percent of reunified wives declared to have migrated exclusively because of family reasons. In fact, 44 percent of these reunified women said they had never worked at their country of origin but were working in Spain at the time of the survey, which does not fit with the idea of 'tied-movers'. In contrast, also as we expected, imported wives the most strongly family-oriented group of migrant women in our sample (77 percent declared only family reasons to migrate).

Insert Table 2 here

b) The legal status of each individual at the time of the survey. Approximately 19 percent of our total sample of non-EU female migrants lacked of proper residency documents in Spain at the time of the survey, 40 percent had been granted a temporary residence permit, 16 percent had a permanent residence permit and approximately 7 percent enjoyed the privileged EU regime because of their family ties with an EU citizen, despite of being third-country nationals. Finally, 14 percent had already acquired the Spanish nationality and, therefore, were not subjected to the foreigners' law anymore. The corresponding percentages for men are quite similar (see Table 3).

c) Whether the individual entered Spain legally or not (individuals who probably held a tourist visa at the time of entering the country but nothing else are classified as illegal entry). NIS did not collect any direct information on category of admission or legal status at entry, but only a semi-retrospective question asking for how long the interviewee has been in the current legal status. By combining this information, responses to other items in the questionnaire (date of arrival, date of arrival of closest relatives to Spain, date of marriage, nationality and country of birth of the spouse, etc.), and information on the rules governing the Spanish system of residence permits, I was able to indirectly reconstruct the legal status at entry of approximately half of our sample. Individuals whose legal status at entry could not be reconstructed from the survey information will remain in the estimated models as 'missing' (see Table 3). 


\section{Results and discussion}

In Table 4, results from Model 1 to Model 3 confirm that the temporal order between one's own migration, marriage and the spouse's migration is a relevant factor in explaining women's post-migration employment, but not that of their male counterparts: none of the categories within the family-migration typology has a statistically significant effect on men's employment probability, while almost all of them are significant for women (compare models 1 to 3 for females in Table 4, with the last column in Table 4 for males). In other words, our results confirm that the determinants of female labour performance at destination are much more complex and heterogeneous than in the case of men. And in the framework of this larger complexity, the sequence of key family life-cycle events like marriage, the woman's own migration and that of her husband appears to have long-lasting effects on female post-migration labour behaviour.

Insert Table 4 here

With regard to the internal heterogeneity of the female immigrant population concerning their employment performance, we also observe some interesting results in Model 1. First of all, single women (i.e. 'not married yet') are not the group most likely to be employed, as suggested by some previous studies. In contrast, the highest employment probability appears among women who are already married but preceded their husbands in their migration to Spain ('potential reunifiers', 'importers' and 'reunifiers', in this order). Obviously, these are quite 'selective' women, especially the potential reunifiers, since they were married before migration but left their husband behind and have not yet brought them to Spain (both the reunifiers and the importers have already joined with their husbands in Spain, although they also preceded them in migration). Taking into account the generally more traditional gender roles and gender ideologies in most of their countries of origin, in comparison to Spain, it seems quite clear that they are a very selected group (in fact, they represent only approximately 6 percent of the non-EU female sample). On the other hand, it is very likely these women made their migration decision after being informed by some other female migrants about the economic opportunities available for them in the Spanish labour market, as 
the results regarding their reasons to migrate suggested (see Table 2). On the other hand, the fact that immigrant women who are still single (35 percent the female sample) are less likely to be employed than the pioneer wives might be related not only to the strong selectivity involved in the migration of the latter, but also to the higher reservation wage that may derive from more years of education and less family responsibilities among the single ones. A proper test of this explanation would require from longitudinal data that allows for a more complete analysis of the complete work trajectories and occupational mobility of different types of immigrant women.

Secondly, what is most important for the main argument here, the coefficient for 'reunified' wives is also positive (see Model 1). As I mentioned in Section 2, this type of migrants have been traditionally identified as the typical 'family-migrant' who is expected to be inactive and economically dependent and, therefore, the basis of much of the negative view that have accompanied family reunification processes in receiving countries. However, our results suggest that these women are not necessarily inactive in the host labour market; in fact, in Spain, reunified wives seem to have a higher employment probability than female migrants who came single and married another immigrant during their stay in Spain (reference category), but also than women who have mix-married in Spain or who have not married yet ${ }^{10}$. In contrast, it is the group of 'imported wives', as expected, the only one that fits the traditional image of the dependant reunified wife.

Jointly, these findings confirm our hypothesis about the crucial role that pre-migration family status plays in shaping the labour behaviour of immigrant women in destination countries. In particular, these findings are consistent with the argument that it is extent to which women were able to participate in their husbands' migration decision as part of their household economic strategy, and not only whether they migrated before or after their husbands, the most crucial factor in predicting the employment patterns of female migrants at destination. Note that this is precisely the main difference between reunified and imported wives: both types of female family migrants migrated after their husbands, but the imported ones where not yet married to their husband - sometimes, they had not even met him- at the time he migrated.

\footnotetext{
${ }^{10}$ Differences between reunified wives and these three groups are all significant at 95 percent level, as we tested by changing the reference category and re-estimating the models.
} 
Next, I tested the robustness of our previous findings once that both current legal status and legal status at entry are controlled for in Models 2 and 3, respectively, since different migration trajectories might be systematically associated with different legal status.

In Model 2, we observe that women with a temporary residence permit (which does not imply necessarily a work permit) are the only group of female migrants with a slightly higher employment probability than the undocumented ones (see coefficient $\mathrm{B}=0.29$ ). However, and surprisingly, neither women with a permanent permit, with an EU family card or naturalised immigrants, who clearly have stronger legal status than the rest, have higher employment probabilities than undocumented ones (see non significant coefficients for all these categories in Model 2). In fact, even if a temporary residence permit provides migrants with legal status, this is a quite precarious one since temporary permits -as I explained in Section 3- need to be renewed every one or two years, and in most cases renewal is dependent on being able to prove legal employment. Two different, and maybe complementary, explanations help understanding these results. First, the vulnerable status of undocumented but also temporary female workers (subjected to periodical renewals of their permits) is what probably makes them particularly attractive for employers in search for cheap female labour. Secondly, it is possible that the higher probability of employment of women with temporary permits simply reflects lower reservation wage of women who hold the intention to return, in comparison to women with intentions to stay more permanently (see Dustman, 1997 for a similar argument). In any case, it seems important to highlight that controlling for current legal status does not change the effect of family-migration categories found in Model 1 (compare Model 1 and 2), which suggests that there is no systematic association between the family-migration sequence followed by female migrants and their current legal status.

Finally, in Model 3 we tested our hypothesis about the negative association between legal entry to Spain and employment among immigrant women, as a result of the perverse set of incentives induced by the labour market structure and the soft enforcement of the Spanish immigration law. The obtained results confirm that women who entered Spain as legal migrants are less likely to employed in Spain than those who 
entered irregularly (see the large negative coefficient of 'legal entry' in Model 3). However, these results must be taken with caution since women with missing information in this variable also appear as less likely to work than the reference category ('irregular entry'). In any case, the results concerning the effects of the familymigration typology remain, once again, virtually unchanged after adding this new control; in contrast, the coefficient for 'permanent residence permit' and 'naturalised' become positive and significant (see Model 3), as we originally expected. In other words, if the negative effect of legal status at entry were not controlled for (as in Model 2 ), the positive effect of stronger legal status at the time of the survey on female immigrants' employment is wrongly underestimated.

So far, the obtained results largely confirm the hypotheses formulated in Section 4. However, it can be argued that these results may obscure large internal differences among migrants coming from different origin countries where the intensity of male labour migration, gender ideologies and the rate of female labour participation greatly vary. In fact, some family-migration trajectories are much more common among particular origin groups than among others. For instance, it might be that the negative effect of being an imported wife on employment found in Table 4 largely reflects the predominance of Moroccans in this category (see Table 5), as Moroccan women are, on average, less likely to be employed than the rest.

In order to examine the extent to which our findings can be generalize to immigrant women as a whole, or they just reflect the particularities of the family-migration trajectories and labour 'quality' of some origin groups in Spain, I re-estimated Model 3 of Table 4 for five separated sub-sample of immigrant women from Morocco, Romania, Ecuador, Colombia and Other non-EU countries. Due to sample size's constraints (see Table 5), some values of the original independent variables were merged into the same category for these new estimations (see in Table 6: potential and actual reunifiers, potential and actual importers, reunified by native and married to a native in Spain, and temporary and permanent residence permit). 
Overall, we find fewer significant effects partially because of smaller samples. However, women who preceded their husband in migration to Spain (actual and potential reunifiers) are clearly more likely to be employed than women in the reference category (married in Spain to another immigrant) among Moroccans, Romanians and Others; for Ecuadorians and Colombians we find the expected positive sign but coefficients are not statistically significant. Moreover, reunified wives appear again more likely to be employed than women who married in Spain to another immigrant among both Moroccans and Romanians, the two largest groups in Spain, and the coefficient is almost significant for Colombians too.

In contrast, the positive effect of joint couple migration seems to be just a 'Romanian effect'. And contrary to our expectations, the negative effect associated with being an imported wife is not a Moroccan effect (see the non-significant coefficient in the first column); in fact, the coefficient for this category is only significant and negative for Ecuadorians and Others.

Finally, marrying a native does not seem to have a consistent effect across groups: while Moroccan women who mix-marry are substantially more likely to be employed than the reference group, Ecuadorian women in mixed couples are substantially less likely to work than the reference category. These sharp differences suggest that selectivity into mixed marriages is a complex issue that to be correctly understood requires a thorough analysis of the characteristics not only of the immigrant partner but also the native ones, which is beyond the purpose of this article.

\section{Concluding remarks}

The obtained results confirm the theoretical and empirical utility of studying marriage and migration jointly in order to explain differences in the labour performance of immigrant women. On the one hand, the previous analyses seriously challenged the stereotypical image of economically inactive reunified wives.. On the other Finally, it is important to highlight that our main results concerning cross-types differences in female labour behaviour remained valid ever after controlling for current 
legal status and legal status at entry, or after splitting the sample according to the country of origin of immigrant women. 


\section{References}

Akresh, I. R. (2006b) "Occupational mobility among legal immigrants to the United States," International Migration Review 40(4): 854-885.

Baker, M. and D. Benjamin (1997) 'The Role of the Family in Immigrants' LaborMarket Activity: An Evaluation of Alternative Explanations', The American Economic Review, Vol. 87 (4): 705-727

Baldwin-Edwards, M. \& Kraler, A. (2009) REGINE Regularisations in Europe. Study on practices in the area of regularisation of illegally staying third-country nationals in the Member States of the EU. Vienna: ICMPD

Brochmann, G. and T. Hammar (eds.) (1999) Mechanisms of Immigration Control. Comparative Analysis of European Regulation Policies. Oxford: Berg.

AUTHOR B and AUTHOR A (2008)

CeiMigra (2008) 'El contingente laboral de trabajadores extranjeros no comunitarios', Observatorio Valenciano de las Migraciones, $\mathrm{n}^{\mathbf{0}} 22$.

Constant, A. and K.F. Zimmermann (2005) 'Immigrant Performance and Selective Immigration Policy: A European Perspective’, IZA Discussion Article No. 1715.

Cerruti, M. and D. Massey (2001) 'On the Auspices of Female Migration from Mexico to the United States', Demography 38: 187-200.

Cornelius, W.,Borger, S. and A. Sawyer (2008) "Controlling unauthorized immigration from Mexico. The Failure of 'Prevention through Deterrence' and the Needed for Comprehensive Reform”. Center for Comparative Immigration Studies, University of California, San Diego.

De Bruycker, P. (ed.) (2000) Regularisations of Illegal Immigrants in the European Union, Brussels: Bruylant.

Donato, K. M. and S. M. Kanaiaupuni (2000) 'Poverty, Demographic Change, and Women's Migration from Mexico' in Brígida Garcia (ed.). Women, Poverty and Demographic Change, New York: Oxford University Press, pp. 217-42

Duleep, H.O. and M.R. Regets (1993) 'The Decision to Work by Married Immigrant Women' Industrial and Labor Relations Review: 677-690

Duleep, H.O. and M.R. Regets (1996) 'Admission Criteria and Immigrant Earnings Profiles’, International Migration Review 30: 571-590.

AUTHOR A (2006a)

AUTHOR A (2006b) 
AUTHOR A (2007)

AUTHOR A (2008)

AUTHOR A (2010)

Hatch, P. (2006) 'Immigration Policy: Family Reunification', LWVUS Immigration Study, Background Articles.

Hondagneu-Sotelo, P. (1994) Gendered Transitions: Mexican Experiences of Immigration. Berkeley, CA: University of California Press.

Jasso, G. and M.R. Rosenzweig (1997) 'Do Immigrants Screened for Skills Do Better Than Family Reunification Immigrants?’ International Migration Review 29: 85-111.

Kanaiaupuni, S. (1995) The Role of Women in Migration: Household Organizational Strategies of Mexican Families. University of Chicago

Kofman, E. (2004), 'Family-Related Migration: A Critical Review of European Studies', Journal of Ethnic and Migration Studies 30: 243-262.

Long, J. (1980) 'The Effect of Americanization on Earnings: Some Evidence for Women' Journal of Political Economy 88: 620-629

Massey, D., Alarcón, R., Durán, J. and H. González (1987) Return to Aztlán: The Social Process of International Migration from Western Mexico. Berkeley, CA: University of California Press.

Massey, D., J. Duran and N.J. Malone (2003) Beyond Smoke and Mirrors: Mexican Immigration in an Era of Economic Integration. New York: Russell Sage Foundation.

Massey, D. and K. Bartley (2006) "The changing legal status distribution of immigrants: a caution”, International Migration Review Vol.39 (2): 469-484.

Meng, X. and R.G. Gregory (2005) 'Intermarriage and the Economic Assimilation of Immigrants' Journal of Labour Economics, 2005, vol. 23 (1): 135-175.

Mincer, J. (1978) 'Family Migration Decisions' Journal of Political Economy 86: 749743.

Nielsen, H. S., N. Smith and A. Çelikaksoy (2007) 'The Effect of Marriage on Education of Immigrants: Evidence from a Policy Reform Restricting Spouse Import', IZA Discussion Paper No: 2899

Parrado, E. (2004) 'International Migration and Men's Marriage in Western Mexico' Journal of Comparative Family Studies 35: 51-72

Sandell, S. H. (1977) 'Women and the Economics of Family Migration' Review of Economics and Statistics 59: 406-414. 
Stier, H. and M. Tienda (1992) 'Family, Work and Women: The Labor Supply of Hispanic Immigrant Wives’ International Migration Review 26: 1291-1313

Zlotnik, H. (1995a) 'The South-to-North Migration of Women', International Migration Review 29: 229-254.

Zlotnik, H. (1995b) 'Migration and the Family: The Female Perspective', Asian Pacific Migration Journal 4: 253-271. 
Table 1. Combined migration and family trajectories of non-EU immigrants aged 16-55 and who arrived at 16 or older, by gender (column \%)

\section{Potential reunifier}

Reunifier

Reunified

Joint couple migration

\section{Potential importer}

\section{Importer}

\section{Imported}

\section{Reunified by native}

\section{Married in Spain to other immigrant}

Married in Spain to a native

\section{Not married yet}

Others (separated, divorced, etc.)

\section{Total}

$\mathbf{N}$

Source: NIS 2007 (INE). Weighted data. Number of observations in brackets.
Marriage- Migration Sequence

\section{Spouses' location at}

survey

Only first mover in Spain

Marriage took place

before migration to

Spain of both spouses

$$
\begin{aligned}
& \text { both in Spain } \\
& \text { both in Spain } \\
& \text { both in Spain }
\end{aligned}
$$

Only first mover in Spain

Marriage took place after the migration to Spain of the first-mover spouse

Marriage took place before the immigrant spouse came to Spain

Marriage took place after migration to Spain

Non applicable

both in Spain

both in Spain

\section{Definition}

Males Females

first-mover migrants who were married before migrating and

$$
\text { did not live yet with their spouse in Spain }
$$

first-mover migrants who were married before migrating and

lived with their spouse in Spain at the time of the survey

(234)

$7 \quad 2$

(299) (80)

second-mover migrants who were married before migrating and lived with their spouse in Spain at the time of the survey migrants married before migration and who migrated to Spain the same year as their spouses

18

(63) (390)

$13 \quad 13$

(466) (519)

first-mover migrant in couples that lived together in Spain at the time of the survey but had married after the migration to

$$
\text { Spain of the first-mover }
$$

first-mover migrant in couples that lived together in Spain at the time of the survey but had married after the migration to

$$
\text { Spain of the first-mover }
$$

second-mover migrant in couples that lived together in Spain at the time of the survey but had married after the migration to

$$
\text { Spain of the first-mover }
$$

\begin{tabular}{cc}
1 & 3 \\
$(87)$ & $(220)$ \\
6 & 7 \\
$(249)$ & $(325)$ \\
5 & 8 \\
$(285)$ & $(593)$ \\
42 & 35 \\
$(1656)$ & $(1602)$ \\
9 & 12 \\
$(381)$ & $(635)$ \\
100 & $(100)$ \\
$(4,122)$ & $(4,888)$ \\
\hline
\end{tabular}


Figure 1. Non-EU foreigners living in Spain 2000-2007

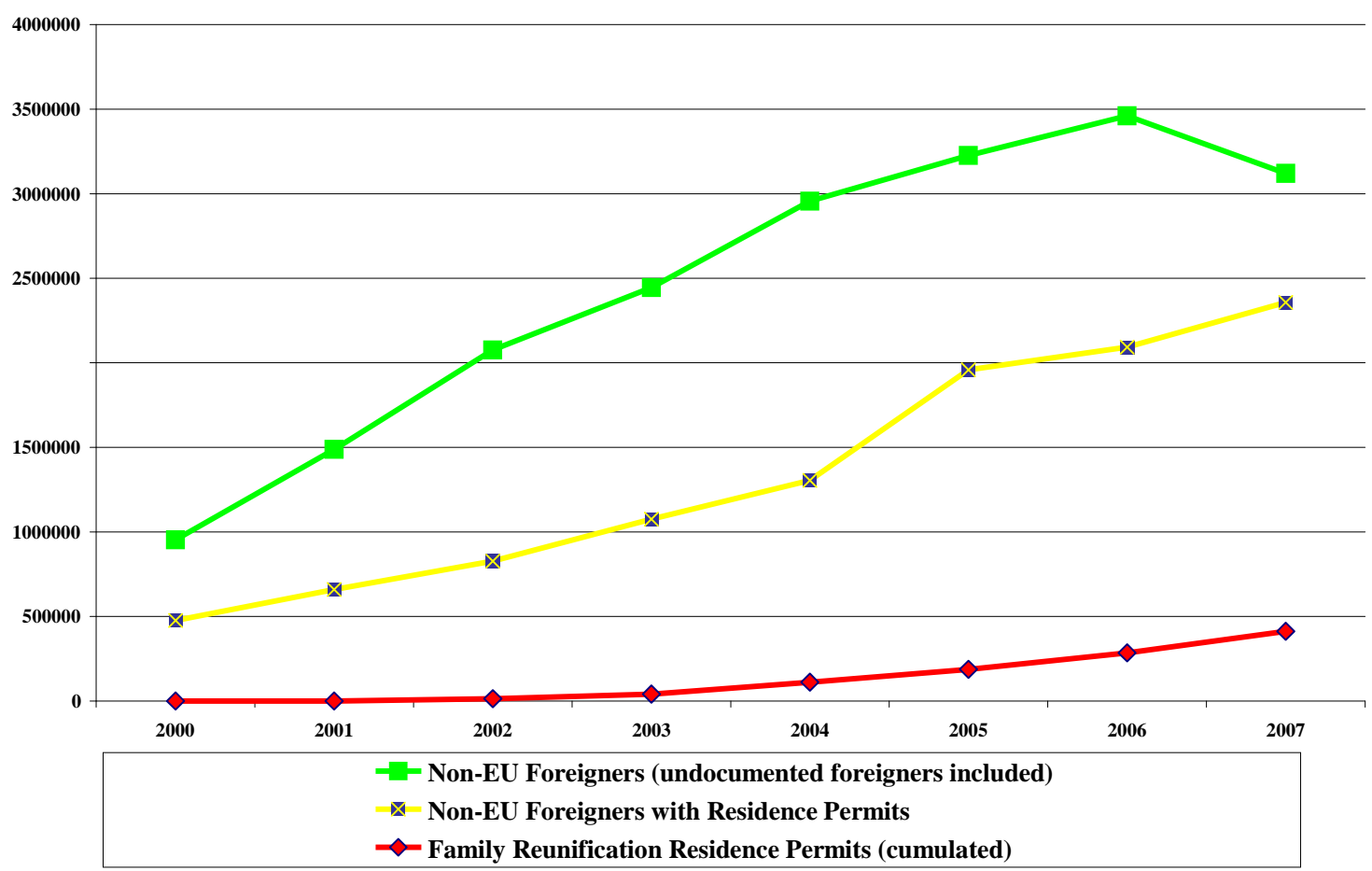

Source: Municipal Population Register and Residence Permit Statistics, several years. Own elaboration 
Table 2. Responses to the question 'Why did you migrate to Spain?' (multi-response possible). Non-EU immigrants aged 16-55 and who arrived at 16 or older, by gender and family-type (row \%).

\begin{tabular}{|c|c|c|c|c|c|c|c|c|}
\hline & \multicolumn{2}{|c|}{ Economic } & \multicolumn{2}{|c|}{ Family } & \multicolumn{2}{|c|}{ Both } & \multicolumn{2}{|c|}{ Others } \\
\hline & Male & Female & Male & Female & Male & Female & Male & Female \\
\hline Potential reunifier & 81 & 74 & 3 & 5 & 4 & 9 & 12 & 12 \\
\hline Reunifier & 88 & 74 & 0 & 4 & 3 & 13 & 9 & 10 \\
\hline Reunified & 45 & 15 & 21 & 47 & 33 & 33 & 1 & 5 \\
\hline Joint couple migration & 65 & 51 & 4 & 11 & 7 & 17 & 24 & 21 \\
\hline Potential importer & 70 & 67 & 2 & 15 & 6 & 3 & 22 & 15 \\
\hline Importer & 71 & 42 & 4 & 31 & 8 & 6 & 17 & 21 \\
\hline Imported & 32 & 8 & 42 & 78 & 25 & 10 & 1 & 4 \\
\hline Reunified by native & 8 & 9 & 38 & 58 & 7 & 6 & 46 & 26 \\
\hline $\begin{array}{l}\text { Married to other immigrant } \\
\text { in Spain }\end{array}$ & 66 & 47 & 5 & 22 & 6 & 12 & 23 & 20 \\
\hline Married to native in Spain & 32 & 42 & 14 & 16 & 3 & 5 & 51 & 37 \\
\hline Not married yet & 60 & 51 & 15 & 16 & 10 & 10 & 16 & 22 \\
\hline Others & 73 & 56 & 5 & 16 & 5 & 8 & 17 & 20 \\
\hline Total & 64 & 45 & 10 & 22 & 8 & 12 & 19 & 20 \\
\hline
\end{tabular}

Source: NIS 2007 (INE). Weighted data. Number of observations in brackets 
Table 3. Legal status (current and at entry) of non-EU immigrants aged 16-55 and who arrived at 16 or older, by gender (column \%)

\begin{tabular}{|c|c|c|}
\hline & Males & Females \\
\hline \multicolumn{3}{|l|}{ Current Legal Status } \\
\hline Undocumented & $\begin{array}{c}18 \\
(563)\end{array}$ & $\begin{array}{c}19 \\
(813)\end{array}$ \\
\hline Temporary RP & $\begin{array}{c}43 \\
(1,765)\end{array}$ & $\begin{array}{c}40 \\
(1,960)\end{array}$ \\
\hline Permanent RP & $\begin{array}{c}19 \\
(914)\end{array}$ & $\begin{array}{c}16 \\
(813)\end{array}$ \\
\hline EU Card & $\begin{array}{c}5 \\
(214)\end{array}$ & $\begin{array}{c}7 \\
(388)\end{array}$ \\
\hline Naturalised & $\begin{array}{c}11 \\
(509)\end{array}$ & $\begin{array}{c}14 \\
(7359\end{array}$ \\
\hline Others & $\begin{array}{c}4 \\
(157) \\
100\end{array}$ & $\begin{array}{c}5 \\
(179) \\
100\end{array}$ \\
\hline \multicolumn{3}{|l|}{ Legal Status at entry } \\
\hline Irregular & $\begin{array}{c}23 \\
(781)\end{array}$ & $\begin{array}{c}28 \\
(1,172)\end{array}$ \\
\hline Regular & $\begin{array}{c}16 \\
(697)\end{array}$ & $\begin{array}{c}18 \\
(952)\end{array}$ \\
\hline Unknown & $\begin{array}{c}61 \\
(2,6449 \\
\end{array}$ & $\begin{array}{c}54 \\
(2,764) \\
\end{array}$ \\
\hline & $\begin{array}{c}100 \\
(4,122)\end{array}$ & $\begin{array}{c}100 \\
(4,888)\end{array}$ \\
\hline
\end{tabular}

Source: NIS 2007 (INE). Weighted data. Number of observations in brackets 
Table 4. Estimates of Employment Probability of Non-EU Immigrants aged 16-55 and who arrived at 16 or older, by gender (logit regression)

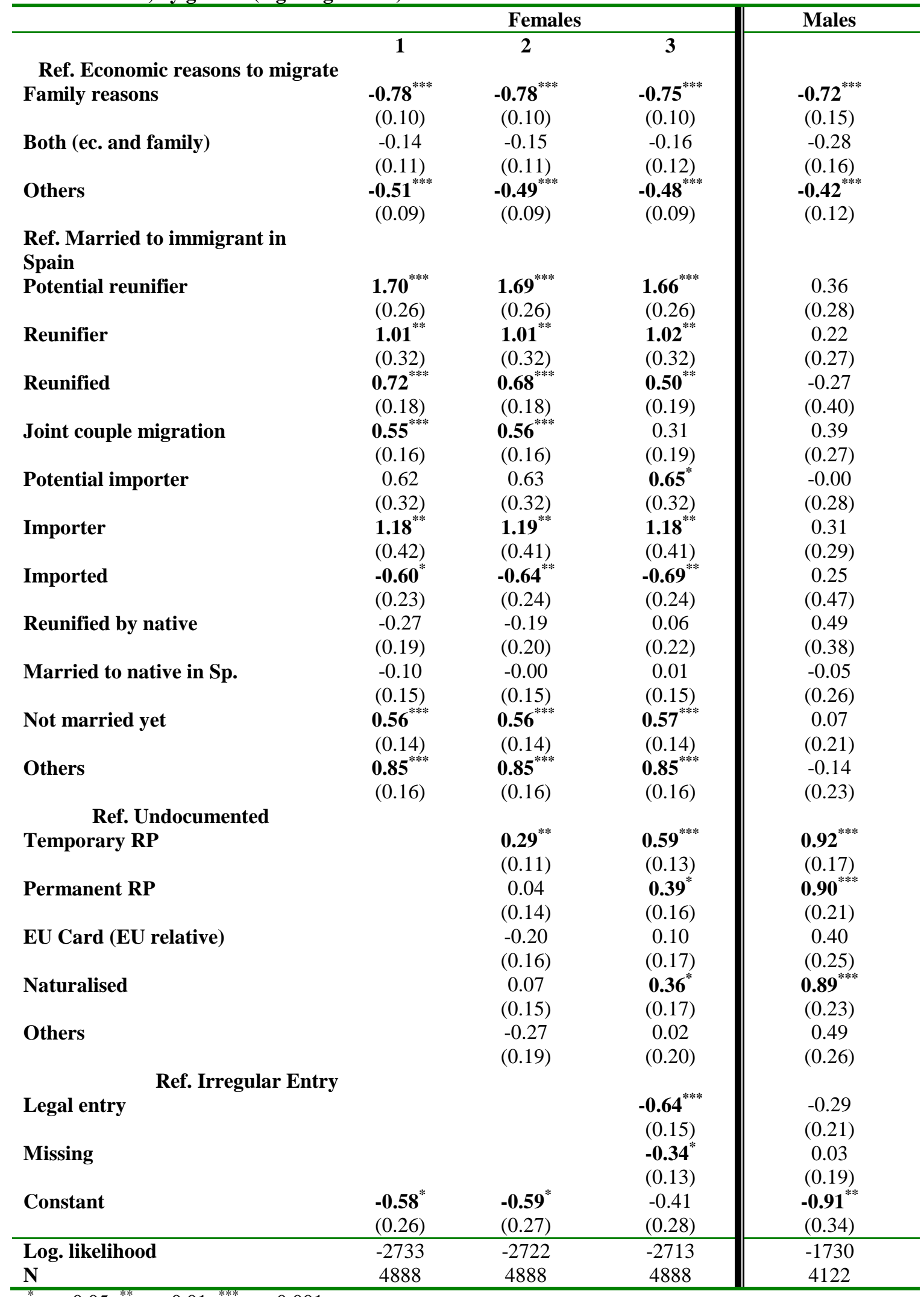

$p<0.05,{ }^{* * *} p<0.01,{ }^{* * *} p<0.001$

Controls for age at migration, years since migration, educational attainment, country of birth, Spanish fluency, ever worked before migration, job proposal before coming to Spain and number of children (results not shown here but available on request) 
Table 5. Combined migration and family trajectories of female non-EU immigrants aged 16-55 and who arrived at 16 or older, by country of origin (column \%)

\begin{tabular}{lccccc}
\hline & Morocco & Romania & Ecuador & Colombia & Others \\
\hline Potential reunifier & 1 & 2 & 3 & 2 & 4 \\
Reunifier & $(7)$ & $(28)$ & $(29)$ & $(12)$ & $(108)$ \\
Reunified & 1 & 2 & 4 & 2 & 2 \\
& $(3)$ & $(12)$ & $(18)$ & $(8)$ & $(39)$ \\
Joint couple migration & 17 & 14 & 8 & 3 & 6 \\
& $(88)$ & $(84)$ & $(54)$ & $(20)$ & $(144)$ \\
Potential importer & 3 & 23 & 10 & 8 & 15 \\
& $(14)$ & $(136)$ & $(58)$ & $(35)$ & $(276)$ \\
Importer & 1 & 0 & 0 & 2 & 2 \\
& $(7)$ & $(4)$ & $(3)$ & $(12)$ & $(38)$ \\
Imported & 5 & 0 & 0 & 1 & 0 \\
& $(22)$ & $(1)$ & $(3)$ & $(2)$ & $(7)$ \\
Reunified by native & 27 & 1 & 1 & 2 & 3 \\
Married in Spain to other & $(155)$ & $(5)$ & $(9)$ & $(10)$ & $(62)$ \\
immigrant & 1 & 0 & 1 & 3 & 5 \\
Married in Spain to a native & $(19)$ & $(4)$ & $(7)$ & $(24)$ & $(166)$ \\
Not married yet & 11 & 8 & 7 & 6 & 6 \\
& $(60)$ & $(59)$ & $(40)$ & $(36)$ & $(130)$ \\
Others & 4 & 5 & 7 & 13 & 9 \\
& $(37)$ & $(50)$ & $(56)$ & $(112)$ & $(338)$ \\
Total & 15 & 34 & 42 & 46 & 36 \\
& $(73)$ & $(217)$ & $(241)$ & $(246)$ & $(825)$ \\
\hline Source: NIS & 12 & 10 & 17 & 11 & 12 \\
& $(80)$ & $(76)$ & $(101)$ & $(65)$ & $(313)$ \\
\hline
\end{tabular}

Source: NIS 2007 (INE). Weighted data. Number of observations in brackets 
Table 5. Estimates of Employment Probability of Non-EU Immigrants aged 16-55 and who arrived at 16 or older, by country of origin (logit regression)

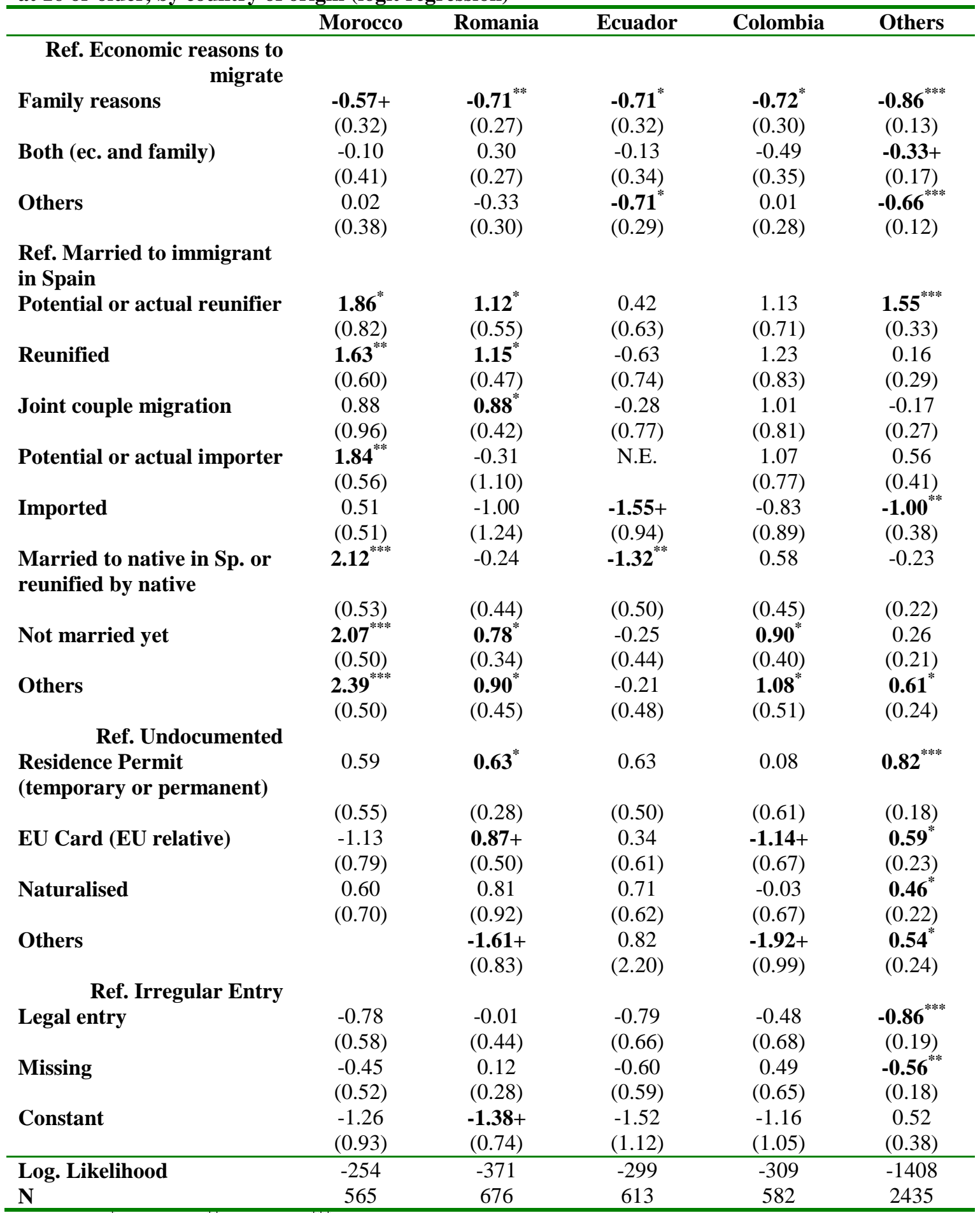

${ }^{+} p<0.10{ }^{*} p<0.05,{ }^{* *} p<0.01,{ }^{* * * *} p<0.001$. N.e.= not estimated due to insufficient cases

Controls for age at migration, years since migration, educational attainment, country of birth, Spanish fluency, ever worked before migration, job proposal before coming to Spain and number of children (results not shown here but available on request) 